\title{
Moiré topography
}

高崎宏

\author{
Moiré topography
}

by Hiroshi Takasaki

\begin{abstract}
A technique observing contour lines of an object by the use of moiré is developed. Shadow of an equispaced plane grating is projected onto an object by a point source and observed through the grating. The resulting moiré is a contour line system showing equal depth from the plane of grating if the light source and the observing point lie on a plane parallel to the grating. A technique to wash away the unwanted moiré and the results of applications are described.
\end{abstract}

\begin{abstract}
まえがき 写真による立体形状測定の特徴は，瞬時に必要な記録を行い得る点にある。しかし，形状 の最も直截な表理である等高線群を得るためには，まず写真を現像し，更に写真の測定と計算，あるい は特別の装置を用いての図化を必要とする。これに対しここに報告する moiré topography は, 物体表 面に，直接に等高線を，モアレ縞によって可視化する方法である。

現在高い精度をもつステレオ写真法も，その原形は，浮き出す写真のみえる覗き箱であった。我々の moiré topography は，現在この誢き箱とあまり変らない器材を用いて行なわれている。従って，現状 で比べるならば精度の点で, 高級な立体写真法に及ばない。しかし, 簡単に, 立体形状を等高線群の形 で観察したい, といいう要求は多い。また, 後述する原理と, 実験結果からわかるように, 誤差源が少 ないために，器材の改良によって，此較的容易に，測定の精度を改善できる見通しがある。そこで，未 完成ながら，一つの新しい方法として，その可能性に注目して報告する。
\end{abstract}

\section{1. 測定原理}

直線等間隔平面格子を物体の上に置き，点光源によ って照明して観察すると，物体表面の等高線群が，モ アレ縞として観察されることは, 従来, 機械工学に拉 ける部材の応力変形の測定に利用されていた1)。しか し, 従来の応用は, 小さくほぼ平面の物体のわづかな 変形の測定に限られていたために，大きな，急な傾き の面をもつ物体に対して, 奥深い所まで, 可視度の高 い縞をあらわす方法, 正確な等高線を観察する条件, 傾斜の急な面にあらわれる不用な縞を消去する方法, 等に関しては，充分な検討が行なわれていなかった。 われわれの方法は，これらの問題点を，解析的に原因 を明らかにして対策を考光，この考觉を実験的に確か める, という手順をくりかえし, 実用的な段階に達し たものである。

\section{1 等標高差等高モアレ縞}

\section{物体が小さく，起伏が浅い場合}

モアレとは，フランス語の moiré一波型をつけた一 の意である。古代中近東地方の特産であった絹織物の

\footnotetext{
* 静岡大学工学部 「写真測量」Vol. 10 No. 21971
}

一種に, 強い織目をもつ布を折り返して押しつけ, 織 目の上に折返された布の織目を型押しした布があっ た。この布は, 現在でも勲章の綬に用いられて拉り, モアレ絹と味ばれるものであるが, 眼の位置や光のあ て方により, 微妙に変化する布の織目よりはるかにあ らい木目状の絞様がその表面に見られる。この絞様 が，通常モアレ縞とよばれるものである。

2 つの周期的な細かい絞様を重ねたとき，ぞのよう なモアレ縞が得られるか, を直截に求める方法とし て，特性式による方法がある。

第1図に拈いて第 1 , 第 2 , の線群を, それぞれ, $p$ まは $q$ をパラメータとして，次式のように書ける とする。

$$
\begin{aligned}
& y=f_{1}(p, x) \\
& y=f_{2}(q, x)
\end{aligned}
$$

これらの線群の交点のらち, 平行に近い角度で交わ れる点は, 連なって, 一つの縞一モアレ縞一として観 察される。

今第 1 図に执いてある特定の縞を形つくる交点につ き $N=q-p$ を求めると, この值は, その点列につい ては，一定值となる。すなわち，モアレ縞は，Nをパ ラメータとする曲線群であり, これを求めるには, 


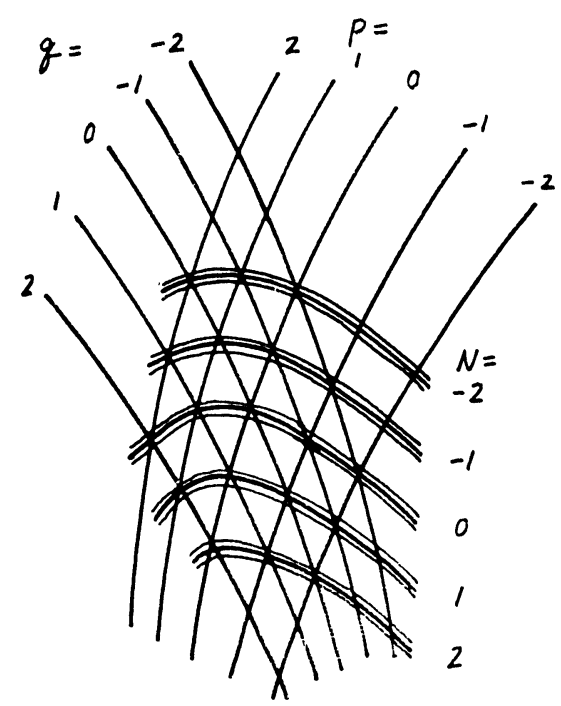

Fig. 1 A moiré pattern generated by everlapping two fine patterns.

（1）式からpを，(2)式から $q$ を，それぞれ $x, y$ の 関数として解き， $N=q-p$ を求めた上で， $x, y$ の関 係をNをパラメータとする形に整理すればよい。

第 2 图に示すように物体の上に，平行格子を置き， これを点光源で照らした場合を考劣る。今あまり大き くない，ほぼ平な物体を考えるならば，格子の条の影 は，物体表面に，平行射影によって落ちると考学てよ い。

格子を，第 3 図 に示すようにある曲線条 $y=f(x)$ を 間隔 $s_{0}$ で平行移動したもの，とすると，格子条すき まの式は， $\varepsilon$ を条すきまの原点に対する位相として

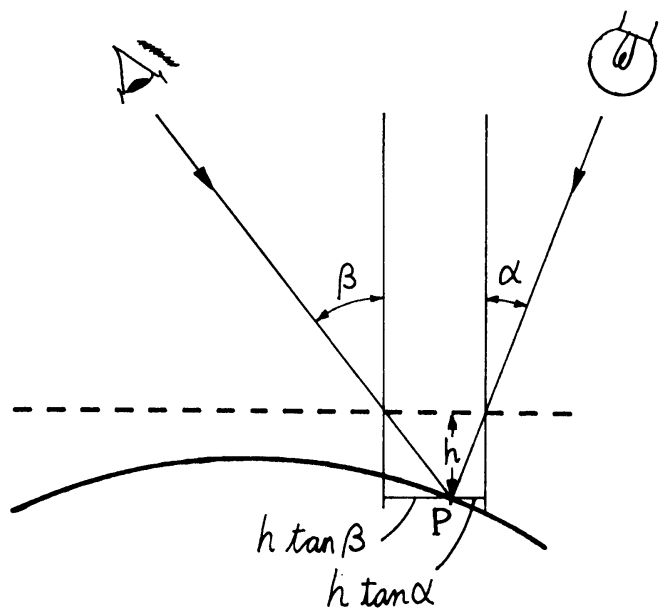

Fig. 2 Vertical projection of light rays of oblique illumination and oblique observation onto a plane which is prependicular to the plane of grating and parallel to the direction of parallel shift of the lines of grating.
(3)式のように書ける。

$$
y=\varepsilon+p s_{0}+f(x)
$$

条すきまをるれて，物体表面洛ちる光の線は，光 の照射角を $\alpha$ とすれば， $h \tan \alpha$ だけづれる。ここで $h$ はp 点の格子面からの深さである。したがって物体 表面に落ちた光の線は(4)式のように書ける。ただ し，図２抹打る角 $\alpha$ は，負の值之考光ている。

$$
y=\varepsilon+p s_{0}+f(x)+h \tan \alpha
$$

一方, 無限遠方から, $\beta$ 方向に, 格子の $q$ 次の条寸 きまを通して見兄る，物体上の線状部分は，（5)式の ように書ける。

$$
y=\varepsilon+q s_{0}+f(x)+h \tan \beta
$$

先の説明にしたがって, (4)，（5）上り $p, q$ を解 き $N=q-p$ を計算して整理すると

$$
N=q-p=\frac{h}{s_{0}}(\tan \alpha-\tan \beta)
$$

$N$ 次の明縞のあらわれる点の格子面からの媣さを $h_{N}$ とすると，

$$
h_{N}=\mathrm{t} \frac{s_{0}}{\operatorname{an} \alpha-\tan \beta} N
$$

試料が小さく，かつ泀ぼ平面で，格子を密着できる 従来の応力変形測定の例の場合には, 光源拉よび観察 点が有限距離にあっても, 近似的に, 平行 光 線 束 照 明，無限遠点よりの観察，とみなせるから，得られる 縞は，近似的に，等高線となる。

平行光線束照明, 無限遠点からの観察, の条件を, 敛密に実現するためには, コリメータを用いて照明 つ，視野レンズの後方焦点面に置かれた小孔を通して 観察する,あるいは写真撮影を行なえばよい。写真 1 は このような装置の一例, 写真 2 は, この装置で撮影し

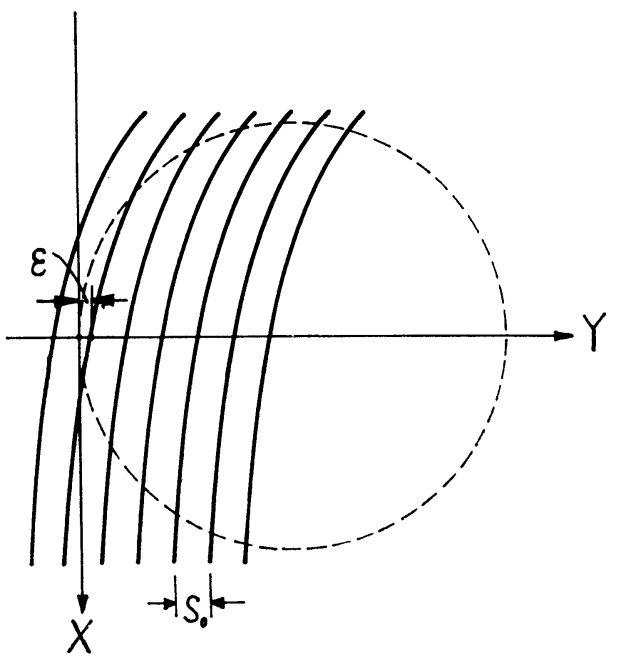

Fig. 3 A parallel grating with curved grating lines. 


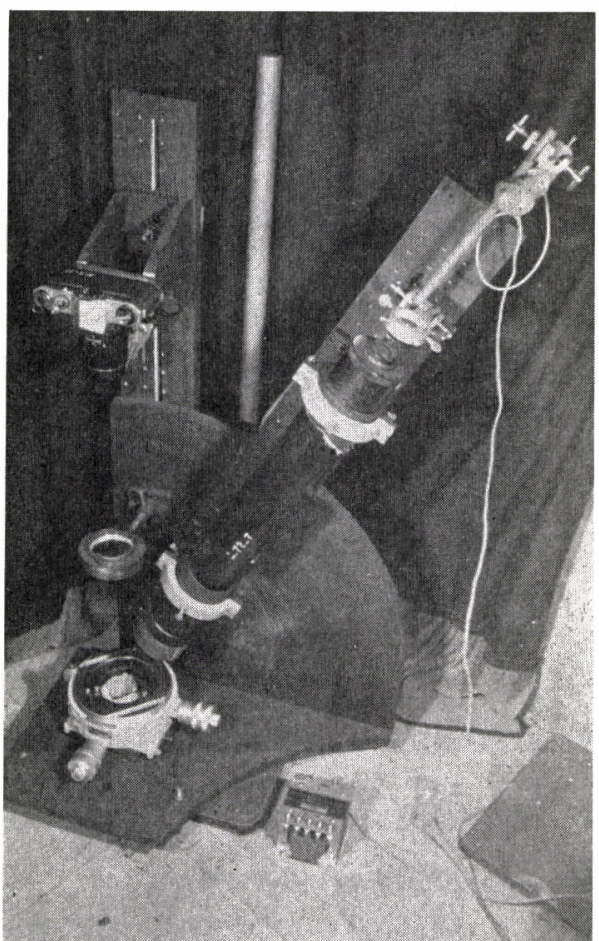

Photo 1 An experimental setup which ensures illumination with parallel ray and observation from infinite distance.

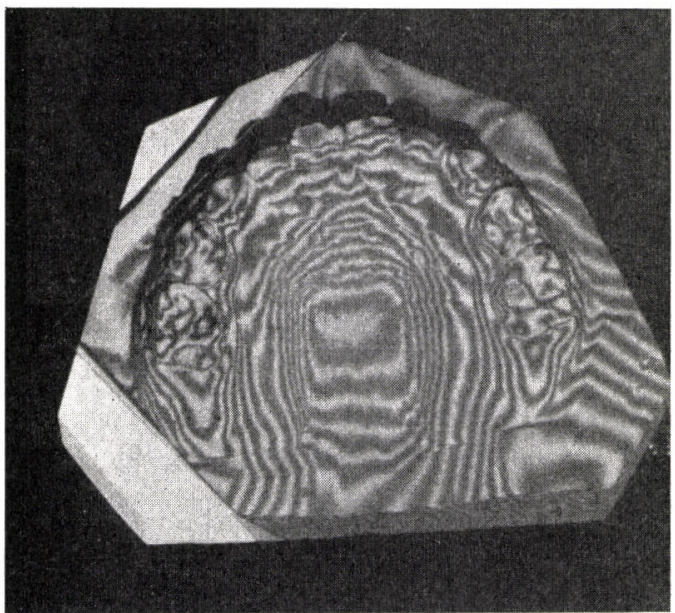

Photo 2 Contour moiré on a plaster model of palate.

た，口蓋石亭模型の等高線縞写真である。

\section{2 急な傾きの面をもつ大きな物体を対象とする} 場合

本節については，旧稿2゙をとのまま再録する。

コリメータを用いる方法では, 試料物体の大きさ は，たかだかコリメータレンズの口径以下である。人 体とか自動車車体などの, もっと大きなるのの測定は

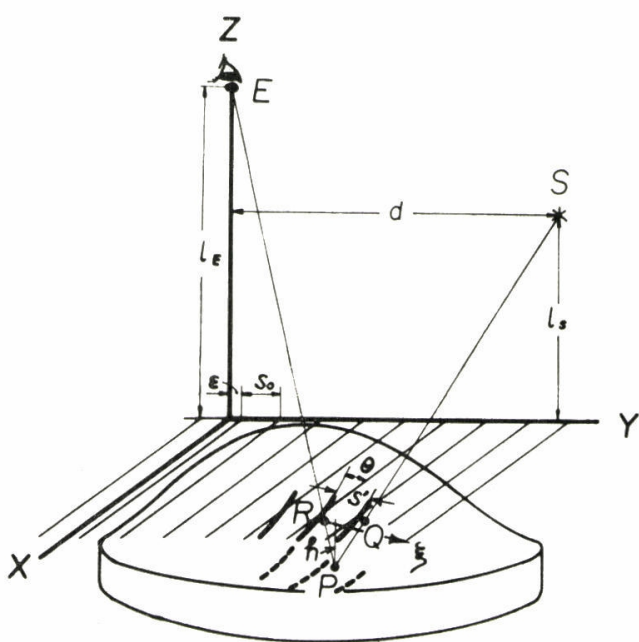

Fig. 4 Schematic representation of moiré topography. A plane parallel grating lies on the $X-Y$ plane. The $X$ axis is taken along with lines of grating. $E$ is the view point and lies on the $Z$ axis. $S$ is a point source which lies on the $Y-Z$ plane. The $y$ coordinate of $S$ is $d$. Heights of $E$ and $S$ fiom the grating surface are $l_{E}$ and $l_{S}$. Line spacing of the grating is $s_{0}$, and $\varepsilon$ is the initial phase of the grating. $\mathrm{P}$ is a point on a surface under test. Depth of $\mathrm{P}$ from the grating surface is $h$, which is taken positive to downward. The slightly curved dotted lines represent the shadow of a small area of grating around $Q$ and the slightly curved thick lines represent a perspective from $E$ of the shadow on the grating plane. The perspective is approximately a grating with line spacing $s^{\prime}$ and line direction $\theta$. The coordinates of $\mathrm{Q}$ and $\mathrm{R}$ are $x_{Q}, y_{Q}$, and $x_{R}, y_{R}$.

\section{できないか？}

糸をわくに張った大きな格子をつくり，これを物体 の前に置いて, 映写電球のような点光源に近い光源で 照らしてみると，ともかく格子と物体上に落ちた格子 の影によるモアレじまが見られる。このしまがどのよ らなものであるかを，一般の場合について考克る（第 4 図)。

格子を通して物体上の $\mathrm{P}$ 点を見るとする。物体上に はQ点近傍の格子の影が投影されて打り, これを格子 のR点近傍を通して観察することとなる。

物体面に投影された格子の影は, その部分の面傾斜 の方向と大きさにより,もとの格子とは方向, 間隔の 異なったものとなっているが，格子の $\mathrm{Q}$ 点は物体上 $\mathrm{P}$ 点に投影されている。この影を目の位置 $\mathrm{E}$ 点につい て, 格子面に射影して得られる縞の方向と, 格子との なす角を $\theta$ とし, この縞に垂直に新しい座標軸 $\xi$ をと $\eta$ ，その縞間隔を $s^{\prime}$ とすれば，見かけの影は(8)式 のようと書ける。 


$$
\begin{aligned}
& I_{S}=\frac{1}{2}\left\{1+\cos 2 \pi\left[\left(\varepsilon+y_{Q}\right) / s_{0}+\xi / s^{\prime}\right]\right\} I_{0} \\
\text { ここで } & \\
\xi & =\left(y-y_{R}\right) \cos \theta-\left(x-x_{R}\right) \sin \theta
\end{aligned}
$$

われわ扎がこの明湆図形を通して見るのは格子のR 点付近であって, この透過率分布は $(10)$ 式のように菖 ける。

$$
T_{R}=\frac{1}{2}\left[1+\cos 2 \pi(\varepsilon+y) / s_{0}\right]
$$

われわれが見るのは（8）の明隌図形に格子の透過 率(10)をかけたものであるから，

$$
\begin{aligned}
I_{M}= & \left\{1+\cos 2 \pi\left[\left(\varepsilon+y_{Q}\right) / s_{0}+\left(\left(y-y_{R}\right) \cos \theta\right) / s^{\prime}\right.\right. \\
& \left.-\left(\left(x-x_{R}\right) \sin \theta\right) / s^{\prime}\right]+\cos 2 \pi(\varepsilon+g) / s_{0} \\
& +\frac{1}{2} \cos 2 \pi\left[\left(y_{Q}-y_{R}\right) / s_{0}+\left(y-y_{R}\right)\left((\cos \theta) / s^{\prime}\right.\right. \\
& \left.\left.-1 / s_{0}\right)-\left(\left(x-x_{R}\right) \sin \theta\right) / s^{\prime}\right] \\
& +\frac{1}{2} \cos 2 \pi\left[\left(2 \varepsilon+y_{Q}+y_{R}\right) / s_{0}+\left(y-y_{R}\right)\right. \\
& \left.\left((\cos \theta) / s^{\prime}+1 / s_{0}\right)-\left(\left(x-x_{R}\right) \sin \theta\right) / s^{\prime}\right] I_{0} / 4
\end{aligned}
$$

この第 1 の $\cos$ 項は投影された影の項を表わし，一般 に去の周波数は格子の周波数とほぼ等しいオーダーで ある。第 2 の $\cos$ 項は格子自身, また第 4 の $\cos$ 項は 格子と影の和の項を表わしている。第 3 の $\cos$ 項は, 影の密度と格子の密度の差と書かれて拈り,ゆっくり した明暗じまとなる。すなわち, モアレじまとして目 に感じられる項である。

この項から，初等幾何学的に次式が求められる。た だし， hは考壳ている点の格子面からの深さである。

$$
y_{Q}-y_{R}=\left[l_{E} d-\left(l_{E}-l_{S}\right) y_{R}\right] h / l_{E}\left(l_{S}+h\right)
$$

この式は座標 $g_{R}$ を含んでいるから, 観察物体上の点 の位置によって, 同じしまが通っていても深さが変わ る。しかし、いま $l_{E}=l_{S}=l$, すなわち, 光源と観察 者のひとみとを格子面から等しい距離に置けば，yの 係数は消觉，(12)式は，

$$
y_{Q}-y_{R}=h d /(l+h)
$$

$N$ 番目の明暗の深さ $h_{N}$ を求めると,

$$
h_{N}=l N /\left(d / s_{0}-N\right)
$$

となって，観察点の位置によらず，ある特定のしまは 格子面から一定の深さ, すなわ七等高線じまとなる。

(14)式は，しまの次数Nを左辺の分母にも含んでい て，钼察点が梁く、Nが大きくなるに従って1しまの ずれに対する標高差が大きくなる。したがって，得ら れるしまは等標高差ではない。しかし, 光源と観察瞳 の格子面からの距離を格子から物体面までの深さに対 して十分大きくとれば，近似的に等標高差等高じまと 考えられるしまが得られる。また，しまの次数さえ正 権に沃定すれば，(14)式から近似なしに，各次のしま

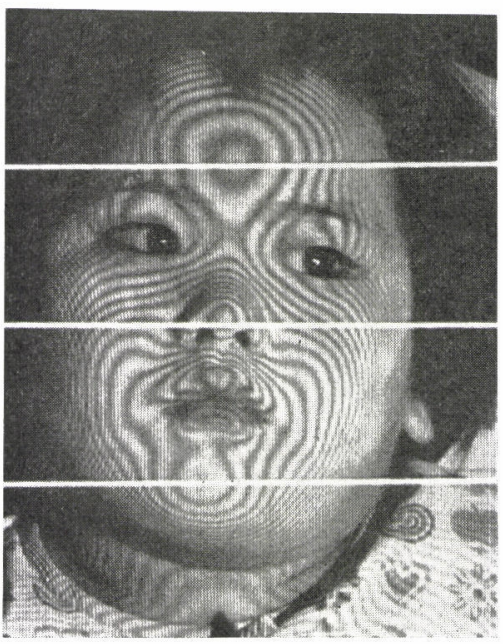

Photo 3 Contour moiré on a face of a baby. This is an example of unsatisfactory result.

の深さを正確に計算することができる。

\section{2. 実験結果}

\section{1 あらわれやすい欠陥と対策}

太さ $0.45 \mathrm{~mm}$ の釣系を、ピッチ $1.0 \mathrm{~mm}$ の長ねじを 枕にして張り，3 M社の拡散性黑色塗料 Nextel 101C 10で整った格子を用い，物体距離 $2.00 \mathrm{~m}$ で写真をと ってみる (写真 3)。一匛の等高線はらつっているが, この写真には, いろいろな問題がある。

奥行の深い所に，縞がはっきりあらわれていない。 これは，光源に有限の大ささがあるために，格子後方 の影に半影のひろがりが加わって，物体上に落らた格 子条の影がぼけること，および，撮影系のレンズ開口 が大きく，物体上に落ちた影と格子条そのものとが， 撮影レンズの物体側焦点深度内に入らず，モアレを生 じなくなるためである。

これらに関しては, 光源として, 点に近いものを, あるいは, 直線状の光源を格子条に平行に用い, 撮影 レンズは，できるだけ絞ることにより，実用的な縞の 得られる奥行を増すことができる。

顔面の縞コントラストが思わしくない。これは，人 間，特に幼児の皮膚が半透明性をもつので，表面に落 ちた格子の影が, 内部执散によってぼけるためであ る。これに対しては，1)被覆力の强い括しろいを好 る，2）格子条を太くし物体面での光の内部拡散の撮影 を，相対的に小さくする，3）照明に青みの光を用い， 皮虞内に侵入した光はよく吸収され，散乱して表面に もどる成分を少なくなるようにする，等の方法が，そ れぞれ単独に，あるいは併用して，有効である。

これらの方法の有効性の実験的証明に関しては, 文 献2)を參照されたい。 


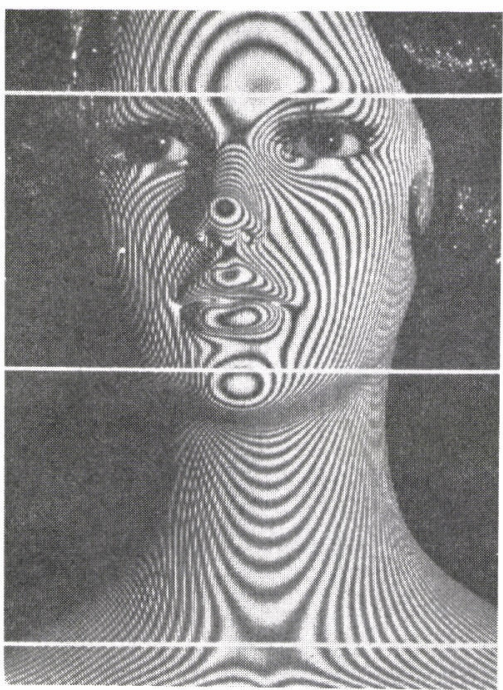

Photo 4 Contour moiré on a face of a mannequin with a stationary grating. Notes unwanted moiré on the cheek.

\section{2 高次モアレ縞之格子条像の消去} 移動格子法

光源と, 撮影レンズの絞りとを吟味した上で, 標高差 $2 \mathrm{~mm}$ の等高線を撮影した例を写真 4 に示す。等高線 は, 縞コントラストについてはよいが, マネキンの額 その他に，格子条去のものが，また，汪汪や首すじに 等高線以外の不用な縞があらわれて見にくくなってい る ${ }^{3,4)}$ 。この不用な縞は, 格子が明暗いづれかの, 矩

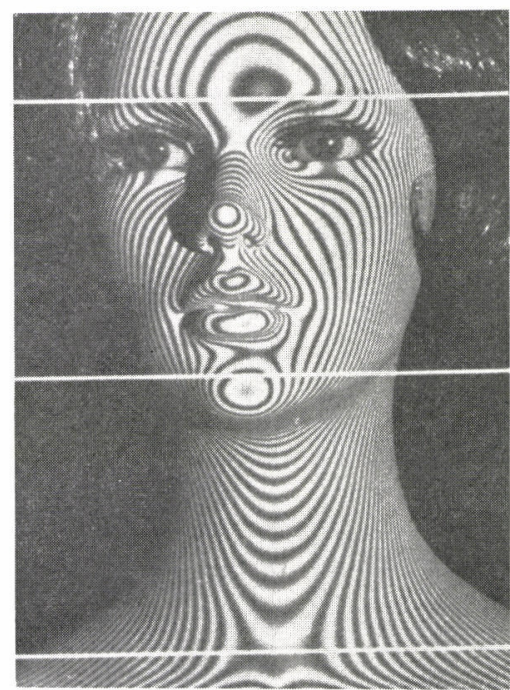

Photo 5 Contour moiré on a face of a mannequin with a moving grating. Note that the shadow of lines of grating and unwanted moiré are washed away.
形状の透過率分布をもつも のであるために発生する。 すなわち，格子の透過率お よび影の強度分布の高次成 分によって生じるものであ $ろ^{3,5)}$ 。

この不用な縞は，格子を 動かすと動く。もちろん格 子条そのものも動く。これ に対し，物体面の明るさ分 布を示す (11) 式に拈ける モアレ縞成分一第 3 の $\cos$ 項一をみると,これには， 格子の位置が含まれていな い。すなわら，等高モアレ 縞は格子をその平面内で平 行移動しても変化しない。 したがって，露光中に，格 子をその面内で，格子周期 長の10倍程度平行移動させると，格子条そのもの，打 よび不用な高次モアレは平均化されて消兄，等高縞の みが残る。写真 5 はこの結果で, 写真 4 に比べ, 縞が 非常に美しくなっている。以上で，活実用になる方 法と条件が明らかになったように思われる。

\section{3 実用テスト} 人体計測の一例
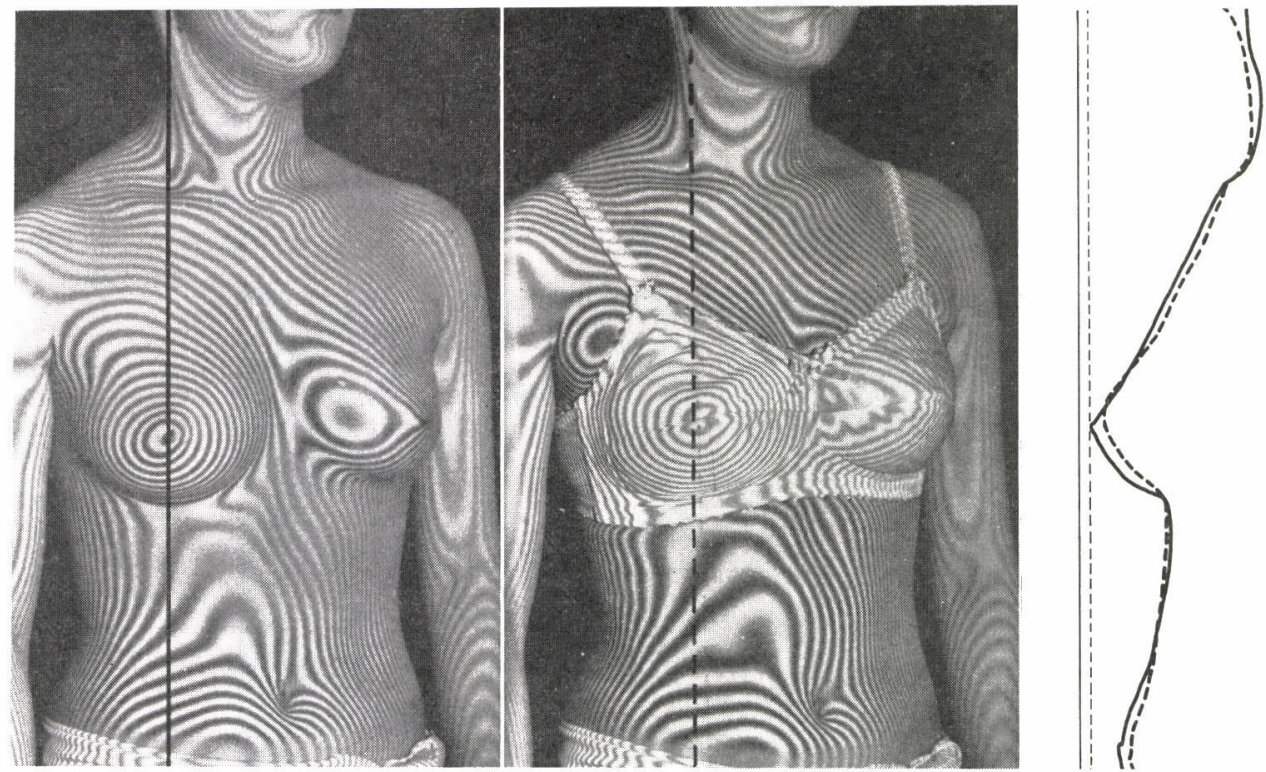

Photo 6 Contour moiré (left and center) and vertical section torough the nipple (right) of breast with and without brasier. 

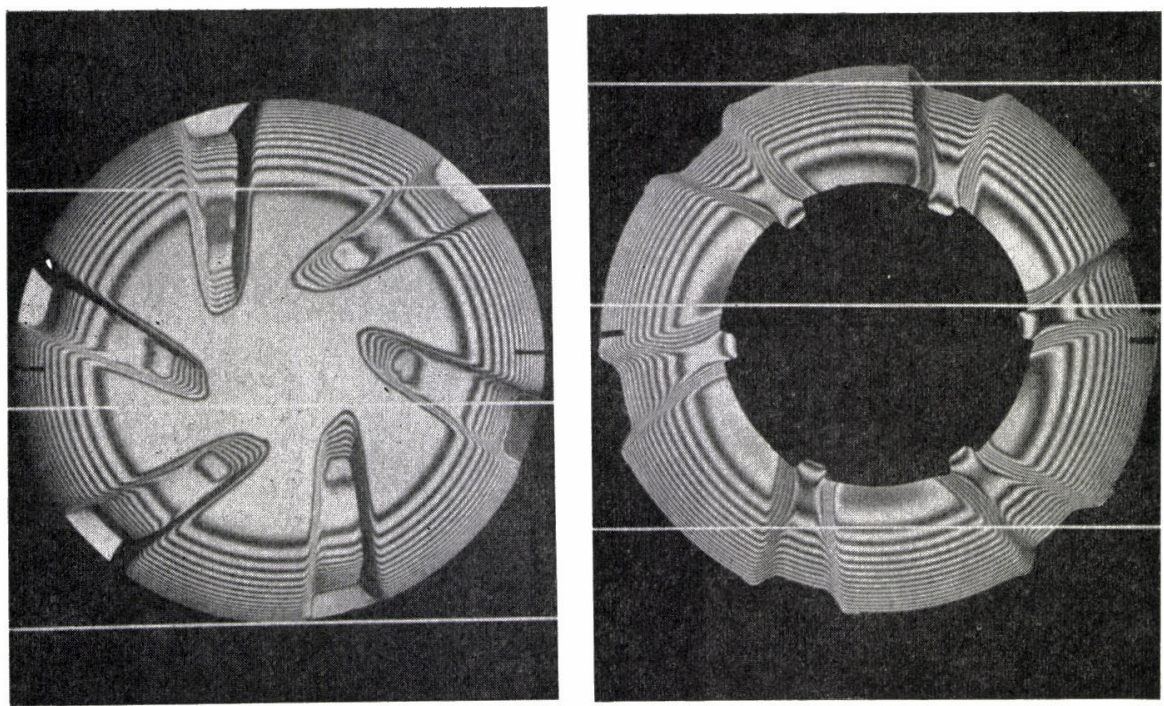

Photo 7 Contour moire of a punch and of the inner surface of a punched work as a sample of contour moiré on a concave surface.

実用性のテストとして，プラジアを付けたときと， 付けないときの上半身の形状に, 標高差 $4 \mathrm{~mm}$ の等高 縞をあらわして写真に撮影した例を，写真 6 亿示す。

(14)式から求まる各次の縞の深さを計算し，写真像 は, レンズ瞳に関する中心投影図であることの補正を 行なえば, 物体表面に定位した等高縞の空間位置を求 めることができる。写真 6 右側の線図は，対応する写 真に，作図によって中心投影の補正を行ない，写真上 に示した縱線に関する断面を求めた例である。ブラジ アを付けたとき(点線) 乳房が持上け゚られており，ブ ラジアが有効に作用していることが知られる。

\section{2-4 凹面にあらわした等高モアレ縞}

写真 6 の腹部を見ると, 凹んだ部分にも, 等高縞が あらわれているのが見られる。これは, 従来の, 等間 隔の光の帯を横から物体上に投げかける, といら方法
では不可能なことである。この特徴を示す例として， プレス加工の雄型と, この型によりプレスされた製品 の, 雄型に面した凹面側の等高縞を, 対比して, 写真 7 に示す。

\section{2-5 面の凸凹の判定}

等高モアレ縞ステレオ写真法

面が凸であるか，凹であるか，の一意的判定は，等 高線図のみでは行なえない。この判定を行なら一つの 方法は，光源と瞳の間隔を少なくして，等高縞の一縞 に対応する奥行の範囲を桩げ, 試料物体の全奥行を, 半縞の中に执さめることである。このようにして凸凹 は，明暗によって示される。

しかし，さらに有効な方法として，ステレオ写真の 併用が考光られる。

(14)式から，ある格子を用い，一定の観察距離で観
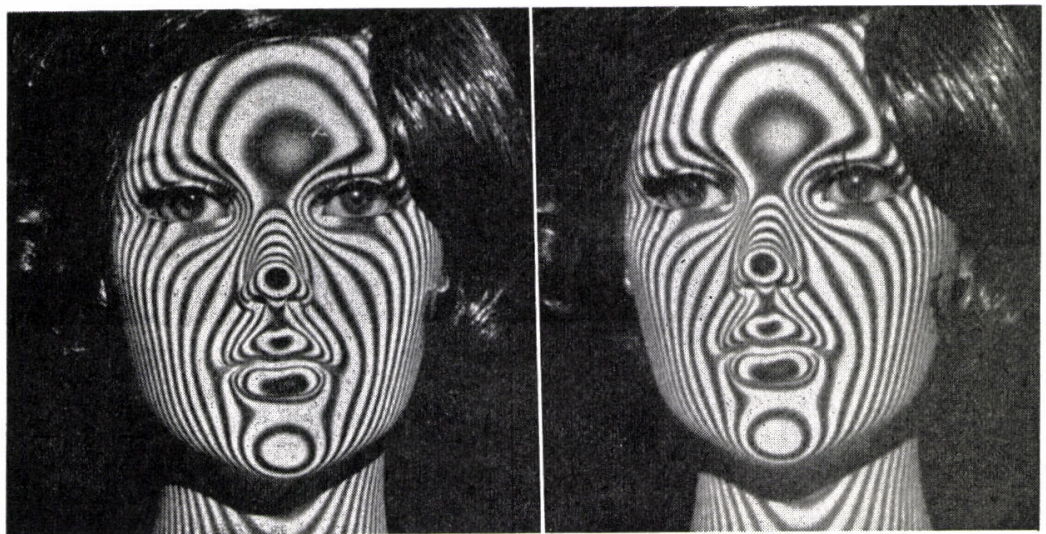

Photo 8 Contour moire stereograph of a mannequin. distance $180 \mathrm{~cm}$, base length $35 \mathrm{~cm}$
測する場合には, $s_{0}$ と $l$ が一定となり, 縞の状態 は，dのみによってきま る。したがって, 視点 $E$ を，格子条に平行な空間 直線上で移動させても， $d$ は変らないから, 縞の 状態も変らない。このよ らに瞳位置を動かして, 物体表面に定位している 等高縞を，異なる視点か ら，写真にとる，すなわ ち, ステレオ写真にとる 

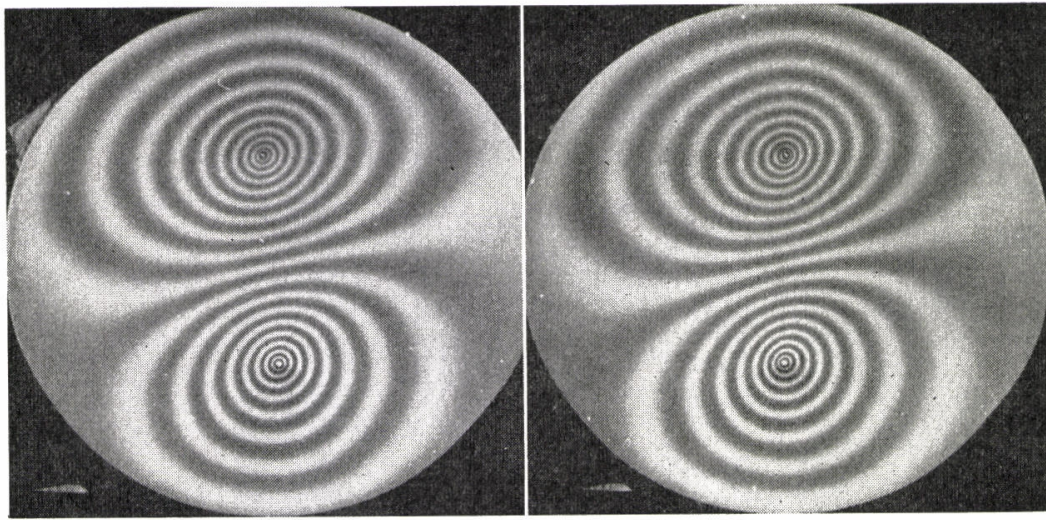

Photo 9 Contour moiré stereograph of a membrane structure. distance $180 \mathrm{~cm}$, base length $40 \mathrm{~cm}$

ことができる。

この方法には，単に凸凹を判定できる，といらこと の他に，大きな利点がある。

一様な表面状態の物体には, ステレオ写真の双眼立
布を一様に張り, 上半の 一点で引き下げ, 下半の 一点で押し上げた幕構造 の写真である。写真 8 の 顔面では，凸凹はすでに わかっているが, 写真 9 の例では, 単一の等高線 写真のみからでは，凸凹 は全く判定できない。ま た, 単にステレオ写真を 撮影しただけでは，幕の 表面状態が一様なので, 引き下げ，押し上げ点が 異なる浮き上りを示すのみで，中間の表面形状は全く わからない。しかし，例示した等高モアレ縞ステレオ 写真を双眼視すると, 表面形状を直ちに立体視でき る。 体視効果が得がたい。そこで, 通常, 意味のない細か

い図形を物体の表面に えがくとか, 光学的に 投影するとかした上で ステレオ写真詨を撮影 する。今われわれの考 えている等高モアレ縞 ステレオ写真法, とで も呼ぶべき方法に㧍い ては，表面の特徴つけ を，等高縞という意味 のある図形によって行 なっている。

写真 8 は, マネキン の顔を，等高モアレ縞 ステレオ写真に撮影し た例である。立体視に よって凸凹の細部を観 察できる他，なんら特 別な装置を用いること なく，単に等高縞をか ぞえることだけで，離 れた部分の高さを比較 したり，鼻の高さを量 的に求めることができ る。

写真 9 は, 伸縮性の

Photo 10 Contour moiré taken by shadow free illumination. The arrows show direction of illumination.
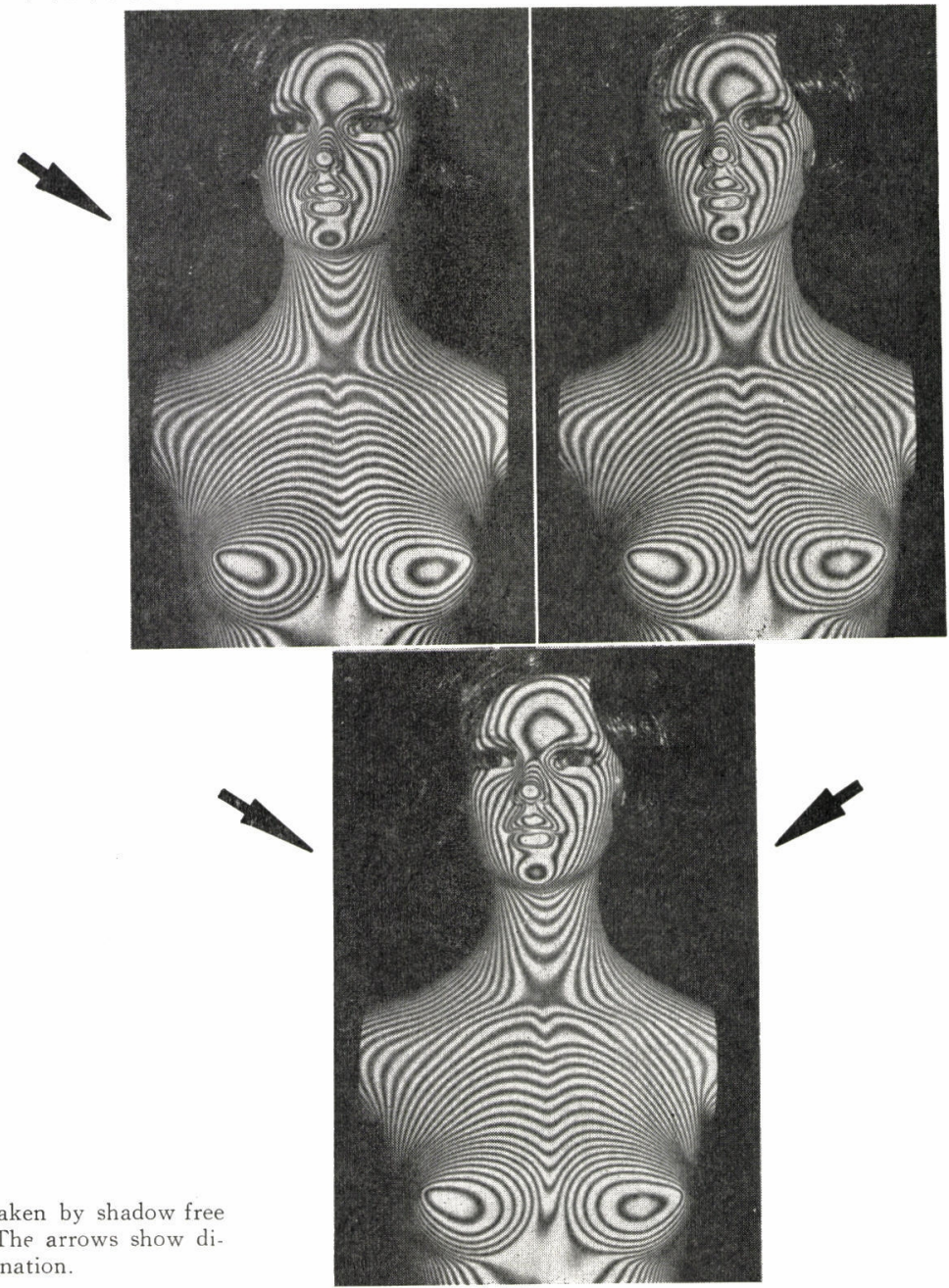


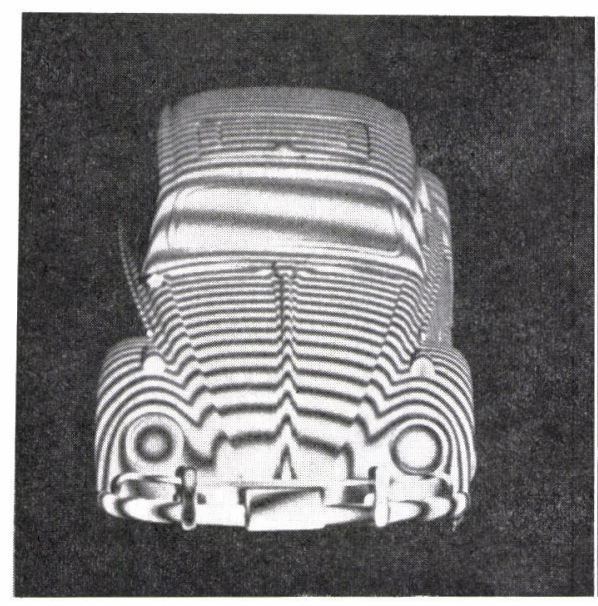

2-6 照明条件の調整 無影照明法

カメラの位置を固定し, 光源を, 格子条に平行な空 間直線上で移動させても，等高縞の状態は变らない。 しかし，照明状態は変化する。したがって，任意の照 明状態を党らぶことができる。等高縞の状態は, 光源 位置が左右入れかわっても， $d$ が等しけれぱ変らな い。したがって, カメラの左右の, 等しいdの位置に 光源を配置して照明すれば，無影の照明を行なうこと ができる(写真10)。

\section{2-7 異なる視点から同一の等高縞を撮影する方法}

さらに, 光源とカメラとを, 相対的に固定し, 一体 として平行移動させると, 同じ等高縞を, 任意の位置 に視点をおいて記録することができる。

写真11 は，自動車模型を格子面に正対させたときの 等高縞すなわら, 横断面図を, 異なる視点から見た例 である。この方法を, 歪曲の少ない広角レンズを用い て実施すれば簡単に正確な立体形状を記録することが
でき，線図の作成にも利用できると思われる。

\section{2-8 あらい間隔の，細い等高モアレ縞}

このよらな応用においては，等高縞を非常に深い所 まであらわさなければならない場合が生じる。このと き写真11例のように, 細かい格子を用いたのでは, 得 られる等高縞が密に過ぎて，かえって見にくい。ま た，縞の得られる奥行が限定される。

格子として, 条幅が広く, 条すきまの小さい, あら い格子を用いと, 格子移動法によって, モアレという よりさしろ光点による作戍，と呼んだ方が適当な働き により, 間隔の大さい, 細い明線でえがかれた断面図 を, 深い奥行まで得ることができる(写真12)。

\section{2-9 瞬間写真}

\section{一液面の測定}

等高モアレ縞は, 常に物体表面に定位しているか ら, 必要に応じ, 映画, あるいは瞬間写真にとること ができる。
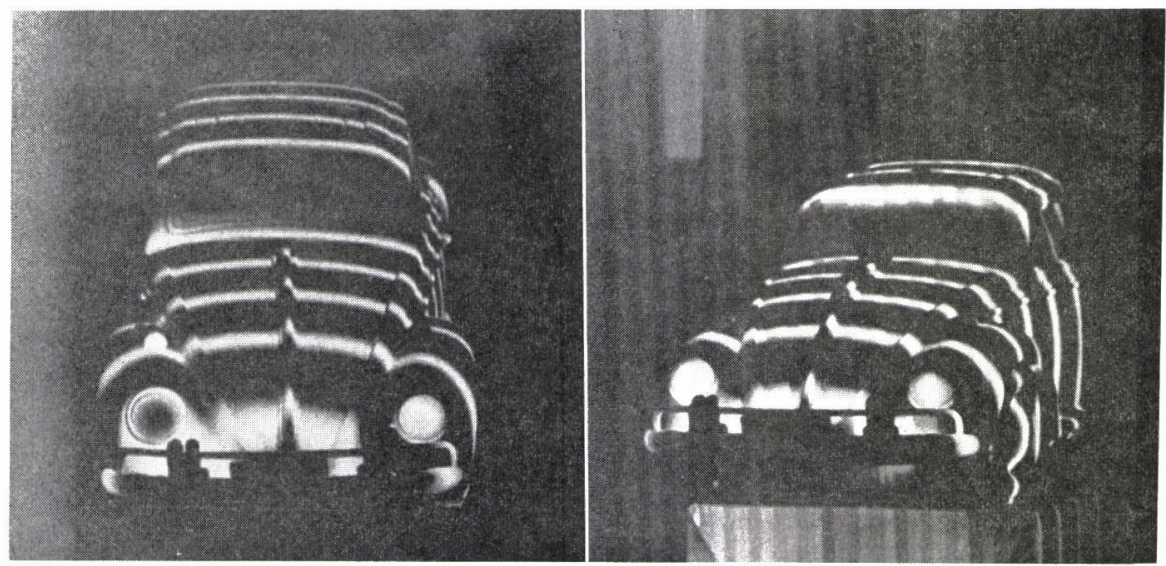

Photo 12 Optically generated line drawing of a model car. 


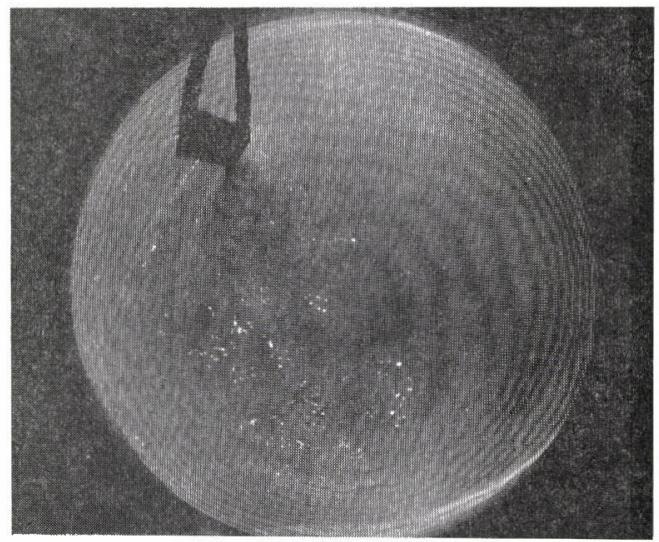

Photo 13 Instantaneous contour moiré of disterbed water surface whitened with water color.

写真13 は, 回転している水を, せき板によって乱し たときの水面を，瞬間写真によって测定した例であ る。この例では, 水性白色顔料で着色してあり, 水面 の傾斜にかかわらず, 弱いけれども一様な縞コントラ ストが得られている。

水面を光に対して反射性にするために，すぐ考光ら れるのは, 塗料用アルミ粉末を撒布することである が,このようにして作られた面は, アルミ粉が薄片状 であるために正反射性が強く, 面の傾きによる明暗が 強くあらわれて好ましくない（写真14）。また, 撒布量 が多過ぎると, 水面に粉末の固まりができる, 水が内 部からわき上る部分の表面膜が切れる, 等の欠点もあ る。

この瞬間測定は, 人体運動機能の解析, 高速回転中

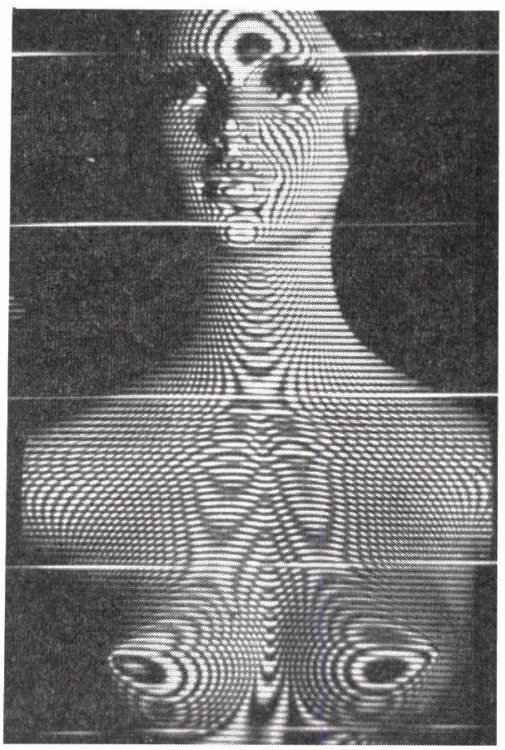

Photo 15 A moiré showing a swell from the representative plane.

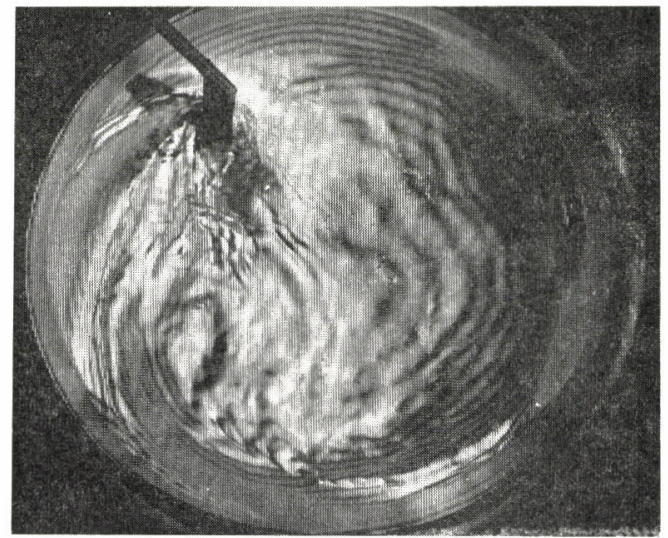

Photo 14 Instantaneous contour moiré of disterbed water surface sprinkled with aluminum powder.

の自動車タイヤの異常変形の測定, 等に利用できると 思われる。

\section{2-10 再モアレ法一}

式( 1 ) （4）の考えを，二つの等高線図に対して適 用すると, これらを重ねることによって生じるモアレ 縞は, 等標高差を示す線群となることが容易に知られ る。

写真15 は, マネキンの上にあらわした等高モアレ縞 の上に，水平等間隔の格子を重水たときにあらわれた 再モアレを示す。

等間隔の格子は, 前さがり, 前あがり, の区別はつ かないが，ともかくある傾きをもつ平面の等高線と考 えられる。したがって, 、ネキンの乳房の上側にあら われた再モアレは, 乳房の上半の, 上あがり平面に対 するふくらみを，下側にあらわれた再モアレは，下さ がり平面に対するふくらみを示す。

この再モアレは, 等高モアレ縞写真の上に, 格子像 を投影して，直接に観察することができる。変倍光学 系を用い, 任意の方向, 間隔の格子像を投影すること は，そうむつかしいことではないから，この方法は， 複雑な形状の立体のある部分を代表する平面を求める ことに利用できて，服飾設計等に便利ではないか，と 思われる。

\section{2-11 変形量の測定}

さらに, この再モアレ法を, 写真16 次頁に示すよう な変形前後の等高モアレ写真に適用すると, 写真17の ように，等変形を示す再モアレが得られる。

再モアレは, 右肩の部分には, はっきりとモアレ縞 として観察されるが, その他の部分では, 等高縞の交 角が大きくなるために，縞としては観察できない。こ 


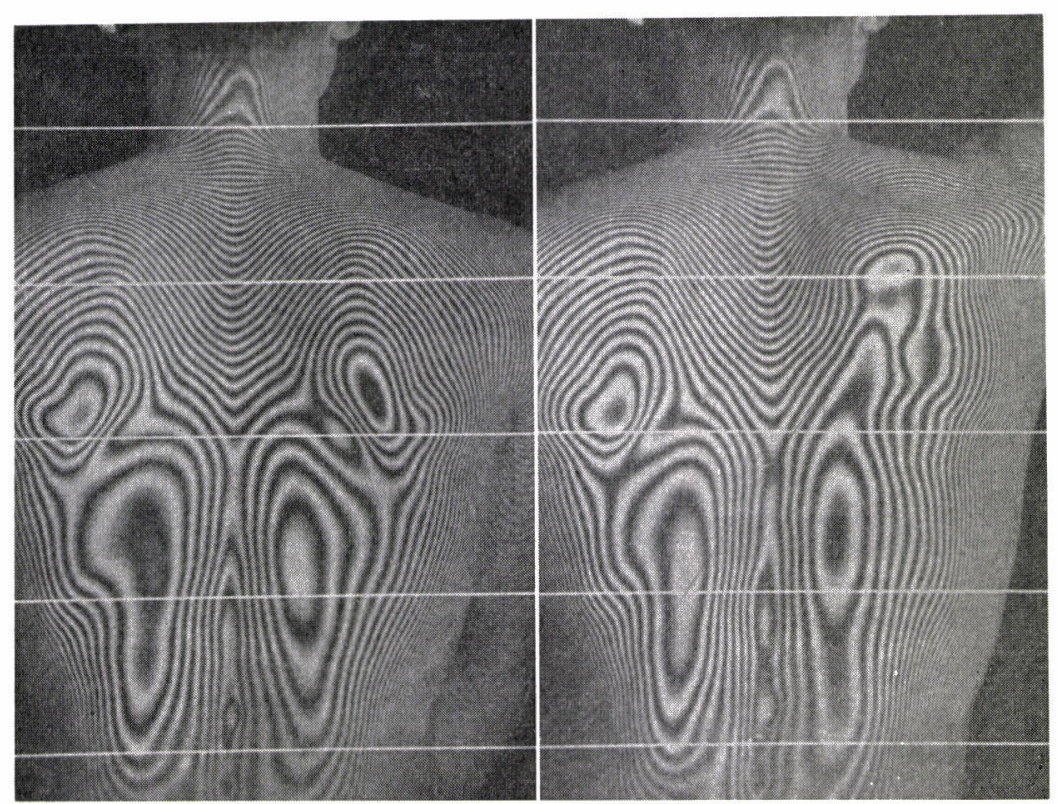

Photo 16 Contour moiré of a human back with right arm down (left) and up (right) position.

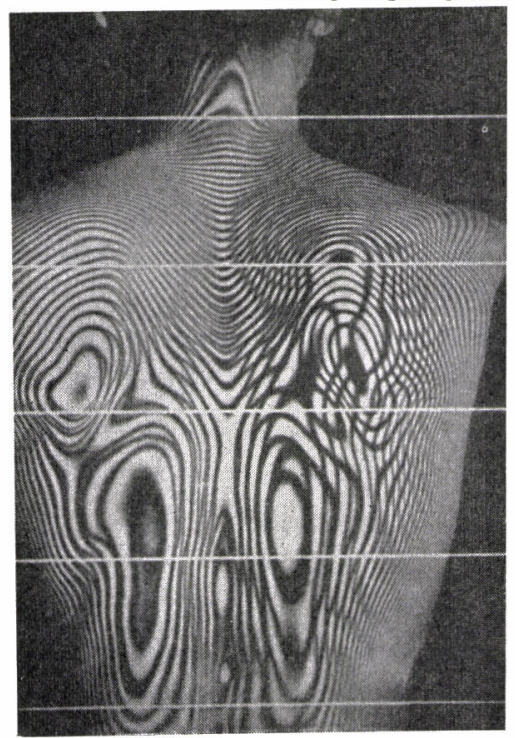

Photo 17 Subtractively engaged two contour moiré of a human back. Note the moiré running near backbone on right shoulder.

れらの部分に対しては, “モアレ縞は, 次数の等しい 交点を結んだ線である”，という考にしたがって写真 17 の上作図儿，第 5 図に示吉等变形線図を求めるこ とができる。この方法は, 顔面修正手術において, 各 部分に必要な修正量を求めることに有効ではなからう か，と思われる。

ただここで注意すべきことは，重㸚られるべき二 つの等高線図が，等間隔等高線図であって，はじめて 再モアレ縞が正確な等変形線となること，および，等
変形線の一縞あたりの変 形差は, もとの等高線の 一縞あたりの標高差に等 しい,といらことである。 したがって, もとの等高 線図は，充分標高差の小 さい密なもので，から等 標高差でなければならな い。

点光源照明による等高 モアレ縞は，等高ではあ るが，等標高差ではな く, 奥行が大きく, 縞次 数が增す程標高差が增す から，この種の写真をそ のまま用いた写真15以下 図 5 までの例は, 厳密に は正確ではない。したが って必要な精度に応じ て, 等標高差等高線図を 作った上で，あるいは観 察距離 $l$ を, 延ぱし, 必 要な近似度で等間隔等高 縞と考克られる原写真を 撮影して適用する必要が ある。

\section{3 - 12 測定精度}

屋根型の標準試料を作 り, 精度をしらべる。 写真18 に示すように, 標 準試料は屋根型 4 ヶを異 なる位置と，向きに配置 したものである。

まず，どの屋根面に も, 棱に平行な縞が得ら れていることから，この 縞は, 解析の示すよら に，試料の部位によらず等高線となっていることがわ かる。

屋根面のダイヤマークの標高差を等高縞から求めた 結果は, 製作目標値 $50.0 \mathrm{~mm}$ と $0.2 \%$ 内で一致した。 標高差のみではあるが，特別な器材を用いずに得られ た精度としては，かなり満足すべきものである。この ように, よい精度を得られたのは, この方法が原理的 に簡明で，実際上の誤差源が少ないためである。も乙 有限物体距離に対してアビオゴン級の低歪特性をもつ 


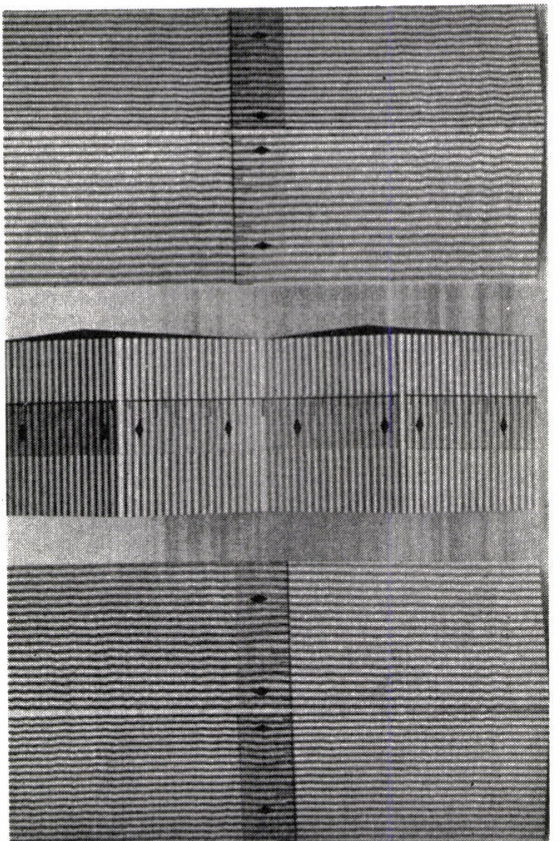

Photo 18 Contour moiré of a standard object for calibration.

広角レンズを用いることができれば，かなりの精度を 要求される目的にも利用できるのではないか，と思わ れる。

\section{3. その他の可能性}

\section{3-1 計算機処理の為の入力作成}

直ちに等高線として記録が得られることは，写真か らデータを作成する上で, 大層有利である。写真19 は 鳃面にあらわした等高縞を, 日本電気 $\mathrm{KK}$ Kが, 大阪万
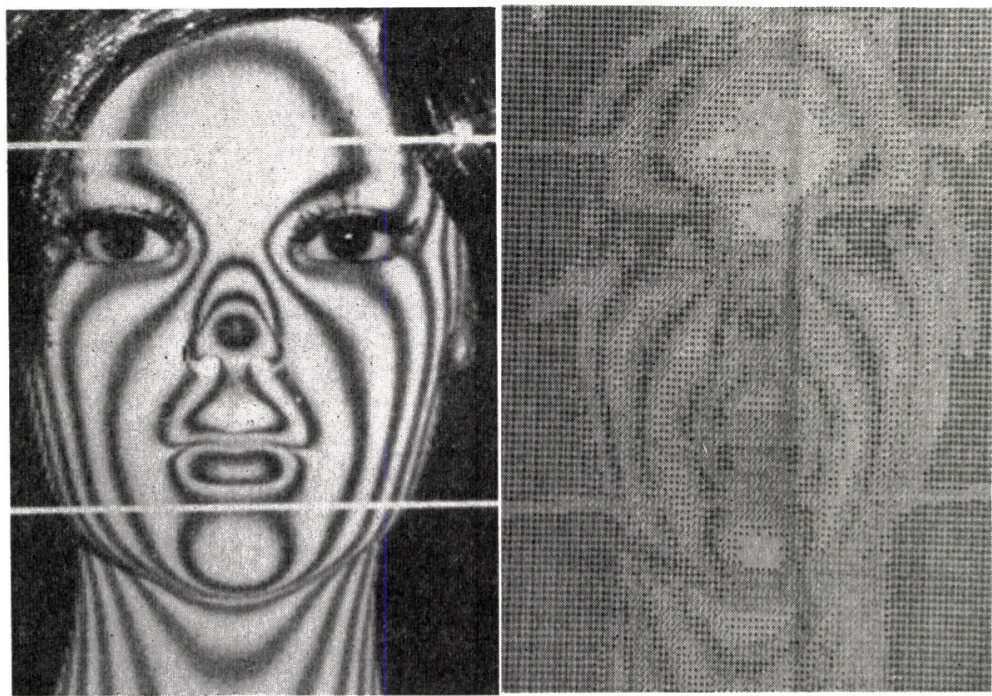

Photo 19 Picture of original contour moiré (left) and contour lines read and printed out by machine (right).

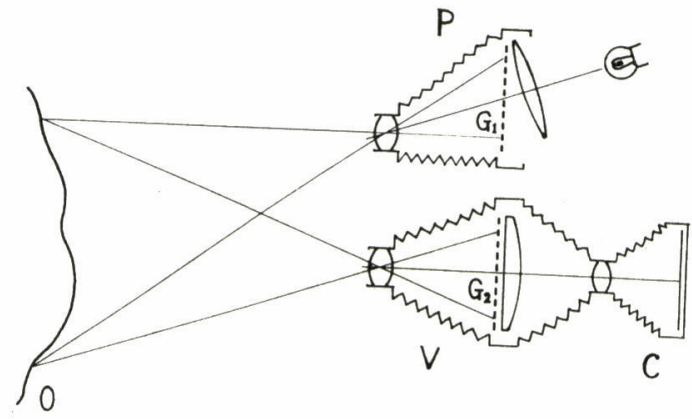

Fig. 6 Schematic diagram of the projection version ofmoiré topography. $\mathrm{P}$ : projector, $\mathrm{V}$ : viewer, $\mathrm{C}$ : camera, $\mathrm{G}_{1}$ : a grating to be projected and $\mathrm{G}_{2}$ : a grating placed on the back focal plane of the viewing system.

国博に展示した画像処理システムによって光電読取り し、プリントアウトした例であって, 計算機処理の入 力作成の可能性を示す。

縞次数による補正を加える必要のある場合には, 走 査による読取りよりも，等高縞を追尾する方法の方が 有利であろう。いうれれにしても, データが, 等高縞と して得られているために, ステレオ法によるデータ読 取りより簡単に行ない得る。

\section{3-2 投影型}

実体格子を試料近くに置きたくない場合，および試 料が大きく実体格子を製作しがたい場合には，第 6 図 に示すように, 実体格子を, 投影器と観察系のレンズに 関して共䡎な小型の格子に置きかえることができる。

この方法に関しては, 昭和 46 年春の精機学会で報告 があったが6)，われわれも，大型鉄板の屈げ加工監視 を対象に検討を行なった。この変形装置は実体格子法

のように, “誤差源が少ない”, といらわけにはほかず, 測定 系としての精度が，使用する 器材の精度に依存する程度が 強くなるが，工業用テレビの 併用で，有効な装置を実現で きる見通しがある。

\section{5. 結 言}

われわれり moiré topography は, あるいは, 再発 見といらべきものかもしれな い。しかし, 発表以来, 多く の分野から関心を寄せられ，

一年経過した現在,すでにか なり実用化されつつある。

その個々の内容について詳 
紐には触れることができないが，主な応用分野は，人 体計測を第一に プレス加工の型之製品心検查, 测 床 風紋, 游底等局部地形の測定, 波, 流水, 回転体, 等つ瞬間形状の測定, および写真フィルムの平面性の 検查，等である。

本研究の実用化に関しては，沼和45年度文部省獄駼 研究資を受けた他, 興和株式会社電気光学部の協力を 受けた。また, 写 6 真は株式会社ワコールより临供を 受姑た。関倸の方々心御礼中し上げる。

\section{文献}

1) P.S. Theocaris: Experimental Mechanics, 4, 153 (1964).

2) 高崎 宏: 画像技術, 2, 27 (1971).

3) H. Takasaki: Appl. Opt., 9, 1467 (1970).

4) D.M. Meadows, W.O. Johnson \& J.B. Allen: Appl Opt., 9, 942 (1970).

5) J.B. Allen \& D.M. Meadows: Appl. Opt. 10, 210 (1971).

6）鈴木正粮他，吉沢徹他：昭和46年度精機学会春期大会 学術講演会前刷, p. 239 , p 245 . 